\title{
Nanomaterials for alternative antibacterial therapy
}

\author{
This article was published in the following Dove Press journal: \\ International Journal of Nanomedicine \\ 10 November 2017 \\ Number of times this article has been viewed
}

\author{
Hassan A Hemeg \\ Department of Medical Laboratories \\ Technology, Faculty of Applied Medical \\ Sciences, Taibah University, Medina, \\ Kingdom of Saudi Arabia
}

\begin{abstract}
Despite an array of cogent antibiotics, bacterial infections, notably those produced by nosocomial pathogens, still remain a leading factor of morbidity and mortality around the globe. They target the severely ill, hospitalized and immunocompromised patients with incapacitated immune system, who are prone to infections. The choice of antimicrobial therapy is largely empirical and not devoid of toxicity, hypersensitivity, teratogenicity and/or mutagenicity. The emergence of multidrug-resistant bacteria further intensifies the clinical predicament as it directly impacts public health due to diminished potency of current antibiotics. In addition, there is an escalating concern with respect to biofilm-associated infections that are refractory to the presently available antimicrobial armory, leaving almost no therapeutic option. Hence, there is a dire need to develop alternate antibacterial agents. The past decade has witnessed a substantial upsurge in the global use of nanomedicines as innovative tools for combating the high rates of antimicrobial resistance. Antibacterial activity of metal and metal oxide nanoparticles (NPs) has been extensively reported. The microbes are eliminated either by microbicidal effects of the NPs, such as release of free metal ions culminating in cell membrane damage, DNA interactions or free radical generation, or by microbiostatic effects coupled with killing potentiated by the host's immune system. This review encompasses the magnitude of multidrug resistance in nosocomial infections, bacterial evasion of the host immune system, mechanisms used by bacteria to develop drug resistance and the use of nanomaterials based on metals to overcome these challenges. The diverse annihilative effects of conventional and biogenic metal NPs for antibacterial activity are also discussed. The use of polymer-based nanomaterials and nanocomposites, alone or functionalized with ligands, antibodies or antibiotics, as alternative antimicrobial agents for treating severe bacterial infections is also discussed. Combinatorial therapy with metallic NPs, as adjunct to the existing antibiotics, may aid to restrain the mounting menace of bacterial resistance and nosocomial threat.
\end{abstract}

Keywords: antibacterial, metallic nanoparticles, microbicidal, nanomedicines, microbial biofilms, antibiotic resistance

\section{Introduction}

Hospital-acquired bacterial infections, mainly caused by the nosocomial pathogens such as Acinetobacter baumannii, Pseudomonas aeruginosa, Escherichia coli, Staphylococcus aureus, Klebsiella pneumoniae and so on, pose the foremost challenge to the well-being of a patient. ${ }^{1}$ The bacteria counteracts the host's innate immune defense machinery, ${ }^{2,3}$ which becomes the prime cause of death in patients confined to the intensive care unit (ICU), with weakened immune system, culminating in invasive bloodstream infections. The widespread use of broad-spectrum antibiotics ${ }^{4}$ has led to the appearance of multidrug-resistant (MDR) isolates that further intricate the clinical problem as the bacteria spread epidemically among the patients. With the 
compromising efficacy of the available chemotherapeutics due to mounting drug resistance and the biofilm recalcitrance towards antibiotics, there is a pressing need to identify alternate drugs. In this respect, nanomaterials have shown promise owing to their unique physical and chemical attributes..$^{5-7}$ Their large surface area relative to volume enables intimate interactions with microbial membranes, as well as surface functionalization, which help in developing more effective antibacterial agents. Over the last decade, there has been a remarkable global focus on conventional as well as biogenic metallic nanoparticles (NPs) as innovative tools for combating the high rates of antimicrobial resistance. Chemotherapeutic drugs when given in combination with metallic NPs may result in a cumulative effect due to the antibiotic as well as the metal ions released from NPs. Moreover, the antibacterial agent may be used at a much lower dose than when administered alone, hence overcoming the problem of resistance and diminishing other undesirable side effects to some extent. ${ }^{6,8}$ There has also been a paradigm shift in management of biofilms and MDR bacteria with polymeric nanocomposites and antibiotic-loaded polymeric NPs. Improved therapeutic efficacy with concomitant decline in side effects of antimicrobial drugs has also been achieved by surface modification of metallic NPs with ligands or antibodies for targeted delivery.

This review summarizes the immune evasion strategies and antibiotic resistance mechanisms employed by bacteria to survive in the host and the probable metallic nanomaterialsbased bactericidal effects to fight against nosocomial pathogens. The antibacterial activities of biologically synthesized metallic NPs as well as polymeric nanocomposites and surface-modified NPs are also highlighted. The metal-based nanomaterials alone or functionalized with antibiotics when translated to clinics may show promise as next-generation nanotherapeutics against bacterial menace.

\section{Gravity of the problem}

Bacterial infections have emerged as the leading cause of the formidable rates of deaths in hospitalized and immunosuppressed patients, especially those in ICUs and those undergoing invasive operations, worldwide ${ }^{1,4,9-11}$ as well as in parts of Saudi Arabia where the prevalence has been reported to be $31.7 \% .{ }^{12}$ The hospital-acquired infections manifest in a wide gamut of severe clinical ramifications, such as bacteremia, septic shock, ventilator-related pneumonia and massive soft tissue necrosis, and rapidly progress to systemic infections that eventually culminate in multiorgan failure and death. ${ }^{13}$ The control measures including implementation of hygiene, patient isolation and environmental decontamination have proved ineffective in keeping the infection at bay. Improper use of antibiotics has favored an upward trend in the development of resistance to almost all the available drugs, further compounding the clinical problem. ${ }^{9,14}$ The challenge to control these infections is augmented in MDR bacteria such as those producing extended-spectrum $\beta$-lactamases and carbapenemases (K. pneumoniae carbapenase) and in methicillin-resistant $S$. aureus (MRSA). Drug combination regimens have also proved ineffective due to formation of biofilms, agglomerates of bacterial colonies that adhere to a surface and resist traditional means of killing by avoiding contact with the antibiotics. ${ }^{15}$ The bacteria survive in the biofilms for extended periods of time and are likely to be transmitted within the health care settings. The quandary of mechanisms of antibiotic resistance has retrogressed the clinical outcome and inflated the economic burden of infectious diseases, leaving the medical practitioners with few therapeutic options to address the emerging threat. ${ }^{14}$ Furthermore, an arsenal of strategies has been employed by bacteria to subvert the host immune system, adversely impacting the surrogate markers of clinical course such as the length of hospitalization and hospital-related deaths.

\section{Bacteria's stratagem: targeting the innate immune defense}

The bacteria have evolved a diverse array of resistance mechanisms to disable key players of the host innate immune defenses for their survival (Figure 1A). They utilize a multitude of virulence factors that conjointly render substantial impediment to phagocytes (macrophages and neutrophils) recruitment and activation. ${ }^{3}$ The bacteria parasitize host cells by arresting or reprogramming phagosomal maturation, by escaping maturing phagosomes or by withstanding the microbicidal properties of the phagolysosome. They acquire resistant proteins to withstand low $\mathrm{pH}$ environment of phagosomes. The bacteria escape neutrophils extracellular traps (NETs) and elude opsonophagocytosis, and the cytocidal effects of host's antimicrobial peptides (AMPs) and reactive oxygen species (ROS). They secrete proteases that cleave NETs, degrade AMPs and express detoxifying enzymes like catalase to neutralize ROS and convert them into less harmful compounds. ${ }^{16}$ Bacteria may also impair ROS production. Bacteria trigger phagocytic death through pore-forming cytolysins and escape host complement deposition and activation. ${ }^{2}$ They release complementdegrading and complement-inactivating enzymes and inhibit membrane attack complex polymerization, thereby impeding bacteriolysis. Self-colonization of bacteria to form biofilms further leads to immune subterfuge. ${ }^{6}$ Bacteria subvert 


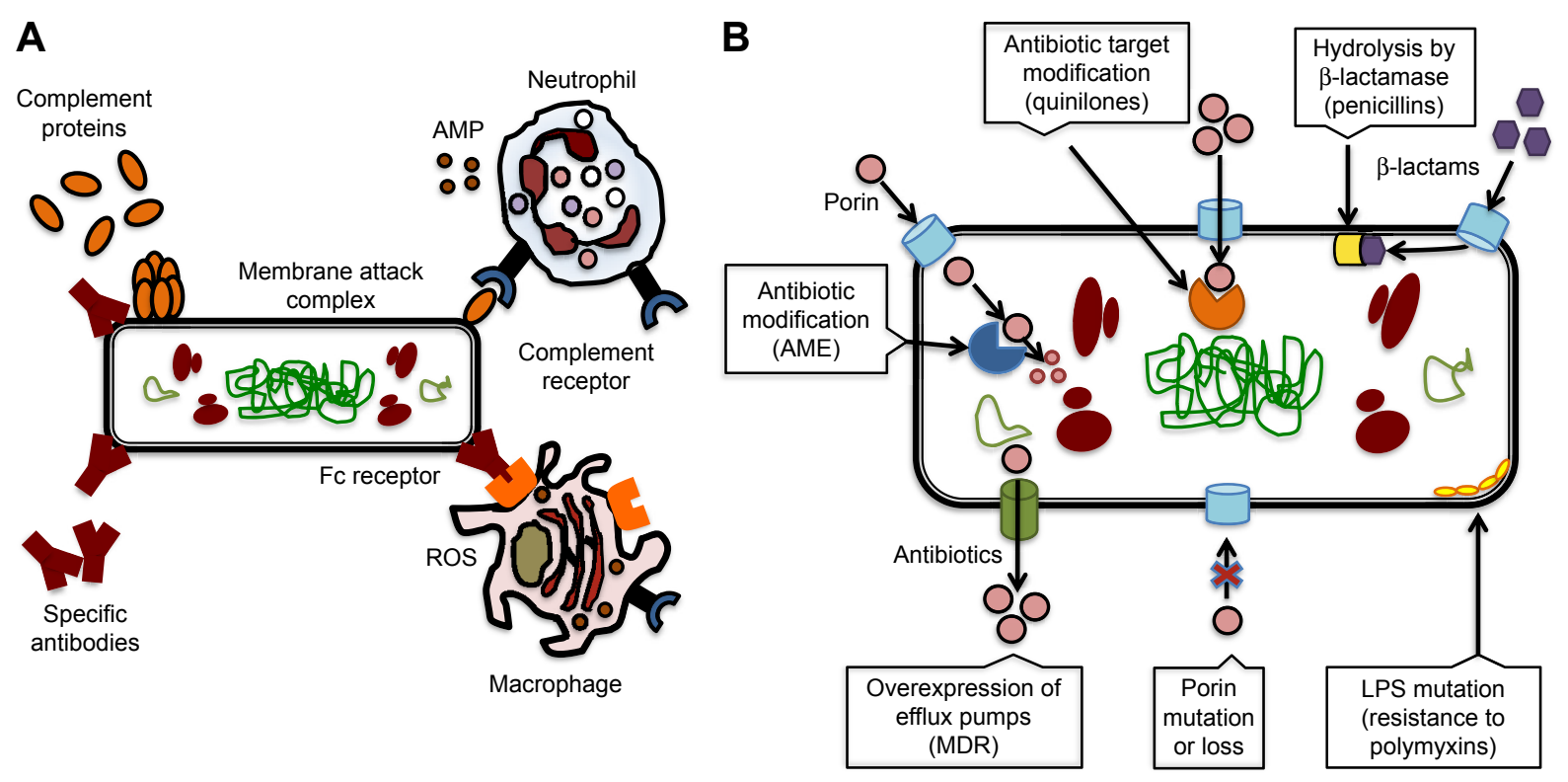

Figure I Strategies for survival in the host to spark invasive infections. (A) Innate immune mechanisms evaded by bacteria include phagocyte (macrophages, neutrophils) recruitment and activation, opsonization via Fc receptors on macrophages, complement activation and the bactericidal activities of antimicrobial peptides and reactive oxygen species. (B) Drug resistance mechanisms evolved by bacteria comprise hydrolysis by $\beta$-lactamases, modification of drug targets or antibiotics, loss or mutation of porins and overexpression of efflux pumps.

Abbreviations: AMP, antimicrobial peptide; ROS, reactive oxygen species; AME, aminoglycoside-modifying enzyme; MDR, multidrug resistant; LPS, lipopolysaccharide.

the $\mathrm{T}$ cell stimulation by dendritic cells (DCs), through downregulation of their antigen-presenting or costimulatory functions. Bacteria may directly infect DC, dampening its interleukin (IL)-12 and tumor necrosis factor-alpha (TNF- $\alpha$ ) production, thereby crippling the adaptive immune response. ${ }^{17}$ Immune evasion favors bacterial persistence, resulting in increased antibiotic use and selection for MDR pathogens, thus emphasizing the need for alternate antimicrobial therapies. ${ }^{16}$

\section{The emergence of antibiotic resistance}

In the present era, the quintessential antibiotics remain the mainstay for management of invasive infections, to annihilate or restrain the growth of a vast spectrum of bacteria. However, this perspective advocates ever-expanding threats accountable to indiscriminate use of antimicrobials resulting in escalated incidence of antibiotic resistance and epidemics of hypervirulent pathogens among vulnerable patients. ${ }^{14}$ Bacteria have progressively eroded the effectiveness of not only a single antibiotic by developing resistance but concurrently multiple drugs that were previously effective. Intracellular bacteria are difficult to treat with regular antimicrobial therapies, resulting in chronic infections. Medical devices such as catheters, implants and sutures increase the risks of nosocomial infections due to formation of biofilms. The biofilm-related infections are extremely defiant to antimicrobial arsenal and spread rampantly in the community. ${ }^{15}$
The normal gut microbiota that otherwise maintains the immune functions is also targeted by antibiotic spectrum. Drug-resistant bacterial infections entail higher doses of drugs, with augmented toxicity, longer hospital stays and enhanced mortality. Thus, antimicrobial resistance remains a substantial global health concern, invigorating the critical need for alternate therapeutic options to combat chronic intracellular infections and biofilms so as to shorten the hospital stays, and hence mortality.

\section{Drug resistance subterfuge evolved by bacteria}

The acquisition of resistance to single and multiple antibiotics by bacteria (Figure 1B) has been reported to occur through horizontal gene transfer on plasmids or transposons by transformation, conjugation and transduction or by spontaneously mutating the existing genes. ${ }^{18}$ The resistance becomes rampant due to selective pressure for microbes expressing resistance genes against the antimicrobial drug, created by overuse of antibiotics, non-patient compliance or use of timedependent drugs with long half-lives or microbiostatic drugs. ${ }^{7}$ Modes of resistance mechanisms ${ }^{19}$ that endanger the efficacy of antibiotic arsenal are summed up as follows.

\section{Active antimicrobial drug efflux and reduced uptake}

Drug efflux pumps preclude the entry of drugs or extrude the antibacterial agent from the microbial cell before it 
reaches its target site to exert its effect. Overexpression of transmembrane multidrug efflux pumps as well as reduced uptake results in sub-toxic levels of drugs within the microbial cells. ${ }^{20}$ In $P$. aeruginosa, mutation in regulatory protein that normally dampens the gene encoding efflux proteins results in enhanced outpour. E. coli uses transmembrane proton gradient to expel multiple antibiotics through its numerous efflux pumps. The increased drug resistance of Gram-positive bacteria is also attributed to the outer membrane surrounding the periplasmic space that restrains the uptake of hydrophobic drugs. The antibiotic uptake or efflux may also be affected by mutations such as the diminished expression or absence of porins in $P$. aeruginosa, lowering the permeability of the cell wall to carbapenems. ${ }^{21}$ In case of both Gram-positive and Gram-negative bacteria, one of the genes encoding tetracycline efflux pumps (TetA) is normally not expressed due to TetR repressor protein. However, tetracycline binds to and inactivates TetR, thereby inducing TetA expression that catalyzes drug efflux. ${ }^{7}$

\section{Expression of resistance gene encoding altered substrate}

The antibacterial agent has diminished affinity for the resistance gene-encoded altered antibiotic target sites on the substrate than the wild-type site. This is exemplified in case of penicillin-resistant Streptococcus pneumoniae (due to MecA gene conferring resistance to all $\beta$-lactams), vancomycin-resistant $S$. aureus and vancomycin-resistant Enterococcus (due to VanA resistance gene), sulfonamideresistant $S$. pneumoniae, Streptococcus pyogenes, Neisseria spp. and E. coli. ${ }^{7}$ This mechanism also accounts for conferring resistance against aminoglycosides, macrolides, $\beta$-lactams, sulfonamides, linezolid, tetracyclines, rifampin and quinolones. ${ }^{7,22}$ Resistance genes coding for enzymes that methylate 23S rRNA of the 50S ribosomal subunit and $16 \mathrm{~S}$ rRNA of the $30 \mathrm{~S}$ ribosomal subunit inhibit binding by macrolides (such as erythromycin) and aminoglycosides, respectively. ${ }^{7,23}$

\section{Covalent modification of antimicrobial drug, dampening its efficacy}

Plasmids or transposons and rarely bacterial chromosomes harbor resistance genes encoding aminoglycoside-modifying enzymes that covalently alter the $\mathrm{OH}$ or $\mathrm{NH}_{2}$ groups on aminoglycosides, thereby undermining their affinity for $30 \mathrm{~S}$ ribosomal subunit, and waning their antimicrobial activity. $\beta$-Lactamases, having broad-spectrum activity against most of the $\beta$-lactam antibiotics, including cephalosporins, have evolved by gene transfer. ${ }^{5,21}$ Chloramphenicol acetyltransferases modify chloramphenicol, making it unable to bind to 50S ribosomal subunit and inhibit protein synthesis. Covalent modification also affords resistance against tobramycin, gentamycin, chloramphenicol, kanamycin, macrolides, tetracyclines, quinolones and streptogramins., ${ }^{7,23}$

\section{Synthesis of a competitive inhibitor of antibiotic}

S. aureus and Neisseria meningitidis acquire sulfonamide resistance by producing its inhibitor (para-aminobenzoic acid) that competes for binding the active site of bacterial dihydropteroate synthetase. ${ }^{7,24}$ Mutations in this enzyme have also been found in many clinical isolates, downgrading sulfonamide-based therapies to second- or thirdline options.

\section{Biofilm formation to avoid contact with antibiotics}

Biofilms are surface-adherent aggregates of bacterial communities embedded within an extracellular, self-produced, polymeric matrix. Intracellular bacteria in biofilms have limited exposure to antibiotics. Biofilms also act as a barrier of diffusion by trapping and degrading antibiotics and thus render tolerance to even high concentrations of antibiotics, a phenomenon called recalcitrance, resulting in recurrent or chronic bacterial infections as with $S$. aureus and $P$. aeruginosa ${ }^{15}$ Biofilms can also favor gene transfer between bacteria, thus spreading antibiotic resistance and transforming a previously non-virulent commensal into a virulent pathogen. ${ }^{25}$

\section{Nanotechnology-based therapeutic interventions to fight nosocomial pathogens}

Several metals, metal oxides, metal halides and bimetals in nanoparticulate form have been documented for antimicrobial activity $^{5,26}$ as the bacteria are less likely to develop resistance to nanomaterials. These comprise NPs containing $\mathrm{Ag}, \mathrm{Au}, \mathrm{Zn}, \mathrm{Cu}, \mathrm{Ti}, \mathrm{Mg}, \mathrm{Ni}, \mathrm{Ce}, \mathrm{Se}, \mathrm{Al}, \mathrm{Cd}, \mathrm{Y}, \mathrm{Pd}$ and superparamagnetic Fe. Zerovalent bismuth-containing NPs have shown promise in treating infections due to drug-resistant bacteria in combination with X-rays. ${ }^{27}$ Among the metalcontaining NPs, Au NPs have moderate antibacterial activity unless their surface is modified. Ag NPs are the most effective nano-weapon against bacterial infections. ${ }^{28-30}$ On the other hand, upsurge in resistance to Ag NPs has been reported due to genetic alterations in bacteria. ${ }^{31}$ The deposition of silver 
of Ag NPs in the liver, spleen, lungs and other organs results in organ damage and dysfunction, and seriously erodes its efficacy. $\mathrm{Al}_{2} \mathrm{O}_{3} \mathrm{NPs}$ promote horizontal conjugative transfer of MDR genes, increasing antibiotic resistance. ${ }^{32}$ The high toxicity of $\mathrm{CuO}$ NPs causes oxidative lesions, while DNA

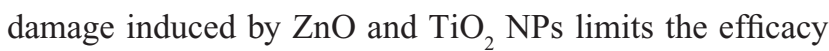
of these NPs. Nonetheless, NPs have emerged as alternative antimicrobial approach to combat biofilms and for treating severe bacterial infections. ${ }^{33}$ The NPs-mediated elimination of the microbes may be microbicidal, or the effect may be microbiostatic, wherein the growth of bacteria is arrested and metabolic activities are ceased and the killing is potentiated by the host's immune cells.

\section{Mode of action of metal-based nanomaterials}

Metallic NPs use multifaceted contrivance simultaneously to combat microbes (Figure 2), depreciating the probability of development of resistance, as it would entail multiple concurrent gene mutations in the same microbe for evolvement of that resistance. The molecular mechanisms by which metalbased NPs annihilate MDR bacteria, resulting in disturbance in respiration and inhibition of cellular growth, have been extensively reviewed. ${ }^{28,29,33}$ Table 1 summarizes the metallic
NPs that have been reported for antibacterial activity via an array of mechanisms enlisted as follows.

\section{ROS generation}

The toxicity of nanomaterials has been attributed to ROS production such as hydroxyl radicals, superoxide anions and hydrogen peroxide that inhibit DNA replication as well as amino acid synthesis and damage the bacterial cell membranes via lipid peroxidation, compromising membrane semipermeability and repressing oxidative phosphorylation. Hydroxyl radical $(\bullet \mathrm{OH})$ formation has been observed with Ag NPs ${ }^{28,29,34}$ and hydrogen peroxide $\left(\mathrm{H}_{2} \mathrm{O}_{2}\right)$ with $\mathrm{ZnO} N{ }^{3},{ }^{35}$ while $\mathrm{TiO}_{2} \mathrm{NPs}^{36}$ produce both via photocatalysis. Free $\mathrm{Cu}^{++}$from $\mathrm{Cu}$-containing $\mathrm{NPs}^{37}$ and $\mathrm{Mg}$ halogen $\left(\mathrm{MgX}_{2}\right)$ containing $\mathrm{NPs}^{38}$ also induce formation of ROS.

\section{Release of metal ions and disorganization of bacterial membrane}

Different microorganisms have varying sensitivities to metal ions. Ag and $\mathrm{ZnO}$ NPs have been reported to exert antibacterial activity by release of $\mathrm{Ag}^{+}$and $\mathrm{Zn}^{++}$that disrupt the membrane. ${ }^{28,29,35,39}$ The antibacterial action of Ag NPs is revealed by interaction of $\mathrm{Ag}^{+}$with sulfhydryl groups in enzymes and other cellular constituents, making them

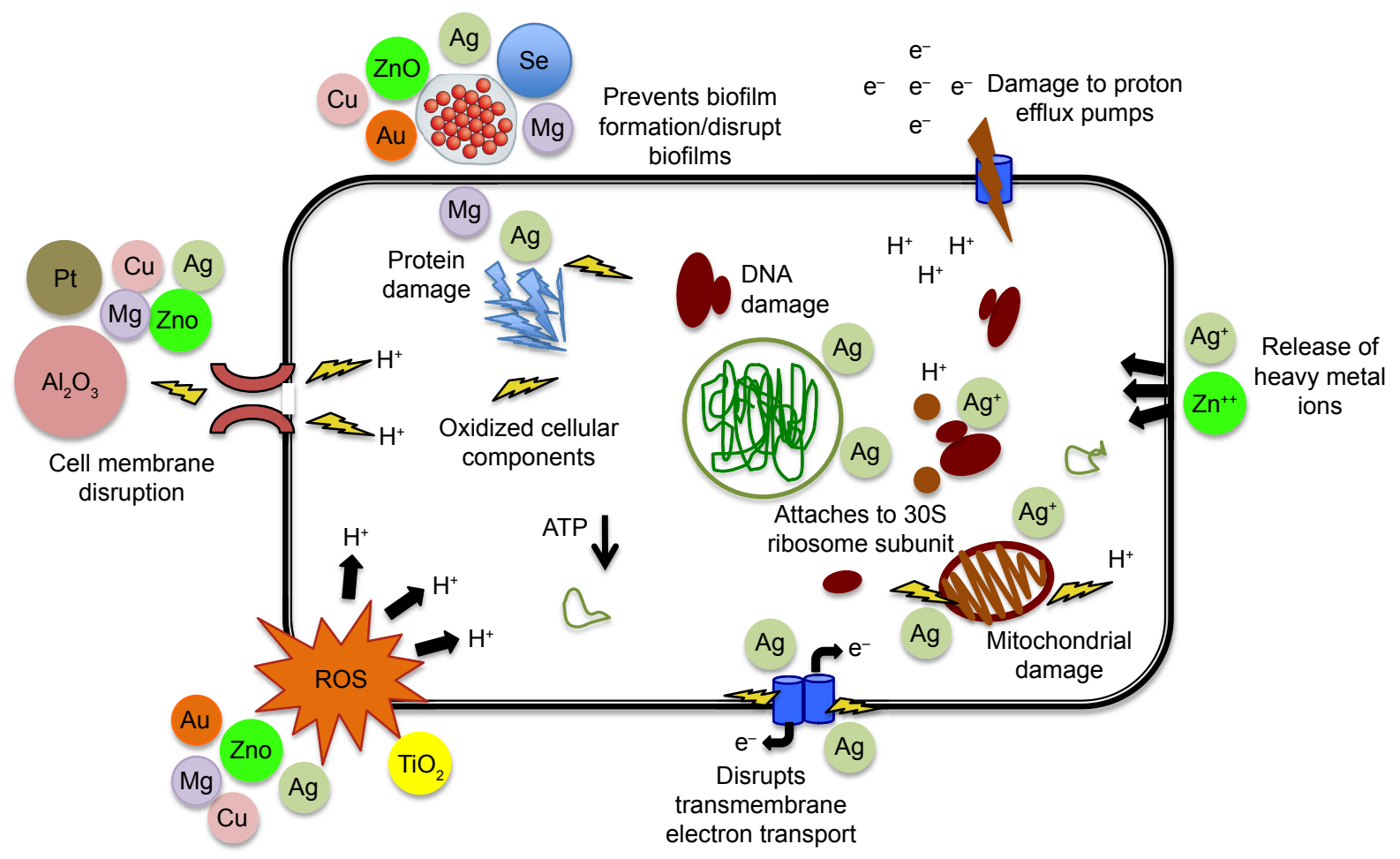

Figure 2 Probable nanomaterials-based bactericidal effects. Nanomaterials trigger release of heavy metal ions that intercalate between bases, damage cellular proteins, disrupt cell signaling, generate free radicals and prevent biofilm formation.

Abbreviation: ROS, reactive oxygen species. 
Table I Metallic nanomaterials-based probable bactericidal effects

\begin{tabular}{|c|c|c|c|}
\hline NPs & Target bacteria & Microbicidal effects & References \\
\hline $\mathrm{Ag}$ & $\begin{array}{l}\text { Acinetobacter baumannii, Salmonella typhi, } \\
\text { Vibrio cholerae, Bacillus subtilis, Staphylococcus } \\
\text { aureus, MDR Escherichia coli, Streptococcus } \\
\text { pyogenes, Pseudomonas aeruginosa, } \\
\text { coagulase-negative Staphylococcus epidermis, } \\
\text { Enterococcus faecalis, Klebsiella pneumoniae, } \\
\text { Listeria monocytogenes, Proteus mirabilis, } \\
\text { Micrococcus luteus }\end{array}$ & $\begin{array}{l}\text { ROS generation, lipid peroxidation, inhibition } \\
\text { of cytochromes of ETC, bacterial membrane } \\
\text { disintegration, inhibition of cell wall synthesis, } \\
\text { increase in membrane permeability, dissipation of } \\
\text { proton gradient resulting in lysis, adhesion to cell } \\
\text { surface causing lipid and protein damage, ribosome } \\
\text { destabilization, intercalation between DNA bases, } \\
\text { disruption of biofilms }\end{array}$ & $28,30,39,52$ \\
\hline $\mathrm{Au}$ & E. coli, S. aureus, B. subtilis, K. pneumoniae & $\begin{array}{l}\text { Loss of membrane potential, disruption of } \\
\text { respiratory chain, reduced ATPase activity, decline } \\
\text { in subunit of ribosome for tRNA binding, bacterial } \\
\text { membrane disruption }\end{array}$ & $4 I, 43$ \\
\hline \multirow[t]{3}{*}{$\mathrm{ZnO}$} & $\begin{array}{l}\text { S. aureus, E. coli, P. aeruginosa, B. subtilis, } \\
\text { Stenotrophomonas acidaminiphila }\end{array}$ & $\begin{array}{l}\text { ROS generation, inhibition of biofilm, } \mathrm{Zn}^{2+} \text { release, } \\
\text { enhanced membrane permeability }\end{array}$ & 35,46 \\
\hline & $\begin{array}{l}\text { Methicillin-resistant Streptococcus agalactiae, } \\
\text { MRSA }\end{array}$ & $\begin{array}{l}\text { ROS production, disruption of membrane, } \\
\text { adsorption to cell surface, lipids and protein } \\
\text { damage, inhibition of microbial biofilm formation }\end{array}$ & 35 \\
\hline & $\begin{array}{l}\text { Enterobacter aerogenes, E. coli, Klebsiella } \\
\text { oxytoca, S. aureus, S. pyogenes }\end{array}$ & Cell membrane interaction & 53 \\
\hline \multirow[t]{2}{*}{$\mathrm{Cu}$} & B. subtilis & $\begin{array}{l}\text { ROS generation, disorganization of membrane, } \\
\text { inhibition of DNA replication }\end{array}$ & 40 \\
\hline & E. coli & $\begin{array}{l}\text { Dissipation of cell membrane potential, ROS } \\
\text { generation, lipid peroxidation, protein oxidation, } \\
\text { DNA degradation }\end{array}$ & 37 \\
\hline $\mathrm{Se}$ & S. aureus, E. coli & Biofilm inhibition & 49 \\
\hline $\mathrm{TiO}_{2}$ & $\begin{array}{l}\text { E. coli, P. aeruginosa, S. aureus, Enterococcus } \\
\text { faecium }\end{array}$ & $\begin{array}{l}\text { ROS generation, adsorption to cell surface, } \\
\text { inhibition of biofilm }\end{array}$ & 36,45 \\
\hline $\mathrm{NiO}$ & S. aureus, Streptococcus pneumoniae & Increase in bacterial cell wall permeability & 44 \\
\hline CdS & E. coli & Antibiofilm activity & 50 \\
\hline $\mathrm{YF}_{2}$ & E. coli, S. aureus & Antibiofilm properties & 48 \\
\hline $\mathrm{MgF}_{2}$ & E. coli, S. aureus & $\begin{array}{l}\text { ROS generation, penetration of cell envelope, lipid } \\
\text { peroxidation, biofilm inhibition }\end{array}$ & 38 \\
\hline $\mathrm{MgO} \mathrm{NP}$ with $\mathrm{Cl}_{2}$ and $\mathrm{Br}_{2}$ & E. coli, Bacillus megaterium, B. subtilis & Adsorption on cell membrane & 54 \\
\hline $\mathrm{Bi} N \mathrm{P}$ & Streptococcus mutans & Inhibition of biofilm & 27 \\
\hline Bi NPs with X-ray treatment & MDR P. aeruginosa & Free radical generation that damages bacterial DNA & 42 \\
\hline $\mathrm{Al}_{2} \mathrm{O}_{3} \mathrm{NPs}$ & E. coli & Cell wall damage, enters cytoplasm & 32 \\
\hline $\mathrm{Ag} / \mathrm{Cu}$ bimetallic NPs & E. coli & Synergistic effect & 55 \\
\hline $\mathrm{Cu} / \mathrm{Zn}$ bimetal NPs & E. coli, S. aureus, MRSA & Antioxidant activity & 56 \\
\hline Ce-doped $\mathrm{TiO}_{2} \mathrm{NPs}$ & E. coli & Membrane damage, penetration of cell envelope & 47 \\
\hline $\begin{array}{l}\text { Ag NPs impregnated with } \\
\mathrm{TiO}_{2} \text { films }\end{array}$ & E. coli, S. pyogenes, S. aureus, A. baumannii & ROS production & 36 \\
\hline $\begin{array}{l}\text { Superparamagnetic iron oxide } \\
\text { NPs coated with } \mathrm{Ag} \text { or } \mathrm{Au}\end{array}$ & $\begin{array}{l}\text { E. coli, S. aureus, P. aeruginosa, E. faecalis, } \\
\text { S. epidermidis }\end{array}$ & Inhibition of bacterial biofilms & 51 \\
\hline
\end{tabular}

Abbreviations: NPs, nanoparticles; MDR, multidrug resistant; ROS, reactive oxygen species; ETC, electron transport chain; MRSA, methicillin-resistant Staphylococcus aureus.

dysfunctional. $\mathrm{Ag}^{+}$also precludes cell wall synthesis in Gram-positive bacteria. $\mathrm{Cu}^{++}$interacts with amine and carboxyl groups on the surfaces of microbial cells, such as Bacillus subtilis..$^{40}$ Au NPs also result in bacterial membrane disruption.

\section{Intercalation between DNA bases}

$\mathrm{Ag}^{+}$released from NPs has also been reported to interact with DNA of microbes, ${ }^{28,29}$ and inhibit DNA replication and cell division. Inhibition of DNA replication and DNA degradation has also been reported with $\mathrm{Cu}$ NPs. ${ }^{37,40} \mathrm{Bi}$ NPs in combination with X-ray treatment emit electrons, with formation of free radicals that damage bacterial DNA. ${ }^{48}$

\section{Adsorption of nanomaterials to bacterial cell}

The electrostatic interaction between the NPs and the microbial cells affects its toxicity, with the positively charged NPs being more toxic as has been observed with $\mathrm{TiO}_{2}$ and surfacemodified Au NPs. ${ }^{36,41}$ The NPs adsorption to the surface of 
bacteria results in oxidative stress due to redox reactions, leading to toxicity. The adhesion of $\mathrm{Ag}$ and $\mathrm{ZnO}$ NPs to bacterial cell surface also results in damage to membrane lipids and proteins. ${ }^{28,29,35}$

\section{Alteration in bacterial membrane permeability}

Cell surface adherence of Ag and polyvinyl alcohol (PVA)coated $\mathrm{ZnO}$ NPs coupled with ROS generation increases membrane permeability and triggers cell death..$^{28,29,35}$ The membrane viscosity is also altered, influencing the transport across the membrane. $\mathrm{Ag}^{+}$released from Ag NPs interacts with negatively charged lipopolysaccharide in the bacterial membrane, permeabilizing it and dissipating the electrochemical proton gradient across the membrane, resulting in lysis.? $\mathrm{Ag}^{+}$inhibits cytochromes of the electron transport chain, and disrupt cellular transport systems by causing homeostatic imbalance due to $\mathrm{K}^{+}$loss from the membrane. Loss of membrane potential and disruption of respiratory chain has also been observed with $\mathrm{Au}^{43} \mathrm{Cu}^{37}$ and NiO NPs. ${ }^{44}$

\section{Penetration of the cell envelope and ribosome destabilization}

The NP surface charge also affects the internalization and subcellular localization and hence toxicity as with $\mathrm{CeCl}_{2}$ NPs. ${ }^{45}$ Entering of NPs into the cytoplasm to exert microbicidal effects via oxidative stress has been observed with $\mathrm{Ag}$ nanomaterials ${ }^{28,29}$ and PVA-coated $\mathrm{ZnO} \mathrm{NPs}^{35}{ }^{35} \mathrm{MgF}_{2} \mathrm{NPs}$ cause lipid peroxidation and enter the membrane of microbial cells, causing a fall in cytoplasmic $\mathrm{pH}$, which raises the membrane potential. ${ }^{38} \mathrm{Al}_{2} \mathrm{O}_{3}$ NPs cause oxidative damage to membrane and enter cytoplasm. ${ }^{32} \mathrm{Ag}$ and $\mathrm{Au}$ NPs have been reported to exert toxicity by penetrating inside the cell and denaturing 30S ribosomal subunit, thereby impeding protein translation. ${ }^{29,30,41}$

\section{Disruption of bacterial biofilms}

During bacterial biofilm maturation, the extracellular matrix (slime) and extracellular carbohydrates known as quorum sensing molecules (for cell-to-cell communication) are produced. ${ }^{46}$ The slow-growing bacterial cells detach, resulting in spread of infection. $\mathrm{Ag}^{28,29}$ and $\mathrm{ZnO} \mathrm{NPs}^{47}$ are also documented to inhibit the microbial biofilm formation. $\mathrm{YF}_{2}{ }^{48}$ and $\mathrm{Se} \mathrm{NPs}^{49}$ restrain growth and biofilm formation of $E$. coli and S. aureus. $\mathrm{TiO}_{2},{ }^{36} \mathrm{CdS},{ }^{50} \mathrm{MgF}_{2}{ }^{38}$ and $\mathrm{Bi} \mathrm{NPs}^{27}$ have also been reported to disrupt bacterial biofilms. Magnetic NPs such as superparamagnetic iron oxide NPs coated with $\mathrm{Ag}$ or $\mathrm{Au}$ exhibit the greatest activity against bacterial biofilms. ${ }^{39,51}$

\section{Antibacterial activities of ecofriendly green NPs}

The potentiality of prokaryotes and plants to reduce inorganic metals has advanced a stimulating, cost-effective strategy towards the NPs synthesis via green nanotechnology. ${ }^{57}$ Plant- as well as microbe-mediated metallic NPs synthesis (bottom-up or biological method) avoids the generation of toxic by-products, and is hence ecofriendly and a green alternative to conventional methods (top-down or physical methods and bottom-up or chemical methods) for mining nanomaterials. ${ }^{58}$ The biologically synthesized metallic NPs are biocompatible and potentially safe for human therapeutic use. A plethora of literature highlights the antimicrobial activities of biogenic metallic NPs (Table 2). Rosmarinus officinalis leaf extract-mediated green synthesis of $\mathrm{Ag}$ NPs has been reported to have remarkable activity against B. subtilis, E. coli, P. aeruginosa and $S$. aureus, ${ }^{59}$ while biogenic Ag NPs from Ficus benghalensis and Acalypha indica demonstrated antibacterial potential against $B$. subtilis, E. coli, P. aeruginosa and Vibrio cholerae.$^{60} \mathrm{Ag}$ NPs synthesized using leaves extract of Skimmia laureola,${ }^{61}$ root extract of Delphinium denudatum, ${ }^{62}$ Styrax benzoin extract ${ }^{63}$ and Rosa chinensis flower extract ${ }^{64}$ showed potent antibacterial effects against a spectrum of Gram-positive and Gramnegative human pathogenic bacteria. Ag NPs synthesized using Caesalpinia sappan extract served as a potential novel nanoantibiotic against MRSA. ${ }^{65}$ Biologically synthesized Ag NPs using Coffea arabica seed extract have been found to exhibit significant antibacterial activity against $E$. coli and $S$. aureus, that was almost equivalent to that elicited with the standard drug ampicillin. ${ }^{66}$ Inhibitory activity of green synthesized $\mathrm{ZnO}$ NPs from Solanum nigrum, ${ }^{67} \mathrm{CeO}_{2} \mathrm{NPs}$ from Olea europaea leaf extract, ${ }^{68}$ and $\mathrm{Fe}_{3} \mathrm{O}_{4}$-Ag core shell magnetic NPs obtained using Vitis vinifera stem extract ${ }^{69}$ against both Gram-positive and Gram-negative pathogens has also been reported. The antibacterial activities of biologically synthesized NPs are due to the metal ions released from the NPs, coupled with the bio-organic compounds used in the green synthesis that may interact with the microbial membrane as well as preclude the need for reducing and stabilizing agent. ${ }^{70}$ However, the biosynthetic NPs have not been found to surpass the non-biosynthetic NPs in antibacterial effects or vice versa.

\section{Immunomodulatory effects of nanomaterials based on metals}

Metal-based NPs are known to trigger innate as well as adaptive immune responses ${ }^{86}$ The immunostimulatory 
Table 2 Antibacterial activities of green NPs

\begin{tabular}{|c|c|c|c|}
\hline Green synthesized NPs & Target bacteria & Antibacterial effects & References \\
\hline $\mathrm{Ag}$ NPs from Phyllanthus amarus extract & MDR Pseudomonas aeruginosa & $\begin{array}{l}\text { Membrane damage, release of free ions, } \\
\text { inactivation of enzymes by interaction with } \\
\text { thiol groups }\end{array}$ & 71 \\
\hline $\mathrm{Ag}$ NPs from Helicteres isora fruit extract & $\begin{array}{l}\text { Extensively drug-resistant (XDR) } \\
\text { P. aeruginosa isolates }\end{array}$ & $\begin{array}{l}\text { Lipid peroxidation, leakage of reducing } \\
\text { sugars and proteins, respiratory chain } \\
\text { dehydrogenases inactivation, turbulence of } \\
\text { membrane permeability }\end{array}$ & 72 \\
\hline $\mathrm{Ag}$ NPs from Artemisia cappilaris extract & Methicillin-resistant Staphylococcus aureus & Membrane damage, release of free ions & 73 \\
\hline $\mathrm{Ag} \mathrm{NPs} \mathrm{from} \mathrm{aloe} \mathrm{vera} \mathrm{extract}$ & Staphylococcus epidermidis, P. aeruginosa & $\begin{array}{l}\text { Release of free ions, increase in membrane } \\
\text { permeability, ROS production, DNA damage }\end{array}$ & 70 \\
\hline Ag NPs from Acalypha indica leaf extracts & Escherichia coli, Vibrio cholerae & $\begin{array}{l}\text { Alteration in membrane permeability and } \\
\text { respiratory chain }\end{array}$ & 74 \\
\hline Ag NPs from Rhizopus oryzae & E. coli, $P$. aeruginosa & $\begin{array}{l}\text { ROS production, membrane damage, } \\
\text { alteration in membrane permeability }\end{array}$ & 75 \\
\hline $\begin{array}{l}\text { Ag NPs from extracts of Cocus nucifera } \\
\text { influorescence }\end{array}$ & $\begin{array}{l}\text { Vibrio alginolyticus, Klebsiella pneumoniae, } \\
\text { P. aeruginosa, Bacillus subtilis, Plesiomonas } \\
\text { shigelloides }\end{array}$ & $\begin{array}{l}\text { Interference with the molecular build-up of } \\
\text { bacterial cell wall }\end{array}$ & 76 \\
\hline $\begin{array}{l}\mathrm{Ag}, \mathrm{Zn} \text { NPs extracted from Caltropis } \\
\text { procera fruits or leaves }\end{array}$ & V. cholerae, E. coli & $\begin{array}{l}\text { Inhibition of adenyl cyclase, restraining } \\
\text { biofilm formation }\end{array}$ & 77 \\
\hline Au NPs from Citrullus lanatus rind & $\begin{array}{l}\text { Bacillus cereus, E. coli, Listeria } \\
\text { monocytogenes, S. aureus, Salmonella typhi }\end{array}$ & Antioxidant activities & 78 \\
\hline $\begin{array}{l}\mathrm{Ag}, \mathrm{Au}, \mathrm{Ag}-\mathrm{Au} \text { bimetallic NPs extracted } \\
\text { from Plumbago zeylanica }\end{array}$ & E. coli, Acinetobacter baumannii, S. aureus & Biofilm inhibition & 79 \\
\hline $\begin{array}{l}\mathrm{Ag}, \mathrm{Au} \text { and } \mathrm{Ag} / \mathrm{Au} \text { bimetallic NPs using } \\
\text { Gloriosa superba leaf extract }\end{array}$ & $\begin{array}{l}\text { S. aureus, Streptococcus pneumoniae, } \\
\text { K. pneumoniae, E. coli }\end{array}$ & Antibiofilm activities & 80 \\
\hline $\mathrm{Ni}$ NPs from Ocimum sanctum leaf extract & $\begin{array}{l}\text { E. coli, K. pneumoniae, S. typhi, B. subtilis, } \\
\text { S. epidermidis }\end{array}$ & $\begin{array}{l}\text { ROS production, release of free ions, } \\
\text { membrane damage, inhibition of electron } \\
\text { transport }\end{array}$ & 81 \\
\hline $\mathrm{Al}_{2} \mathrm{O}_{3} \mathrm{NPs}$ from leaf extract of lemongrass & MDR P. aeruginosa & $\begin{array}{l}\text { Intracellular oxidative stress contributing to } \\
\text { loss of cell membrane integrity }\end{array}$ & 82 \\
\hline $\begin{array}{l}\text { Pd NPs using agroforest waste Moringa } \\
\text { oleifera }\end{array}$ & $\begin{array}{l}\text { Enterococcus faecalis, B. cereus, S. aureus, } \\
\text { E. coli }\end{array}$ & Antioxidant activity & 83 \\
\hline Se NPs from Bacillus licheniformis & $\begin{array}{l}\text { B. cereus, E. faecalis, S. aureus, E. coli, } \\
\text { S. typhi, Salmonella enteritidis, S. aureus }\end{array}$ & Antibiofilm activity & 84,85 \\
\hline
\end{tabular}

Abbreviations: NPs, nanoparticles; MDR, multidrug resistant; ROS, reactive oxygen species.

potential of $\mathrm{Ag}, \mathrm{CeO}_{2}$ and surface-modified Au NPs has been reported ${ }^{87}$ Immunostimulatory NPs may serve as doubleedged swords by acting on bacteria as biocidal nanoweapons, as well as undermining the bacterial resistance to host immunity. ZnO NPs increased interferon gamma, TNF- $\alpha$ and IL-12 expression in primary human immune cells, ${ }^{88}$ while in another study, IL-6, IL-1 $\beta$, IL-8 and TNF- $\alpha$ were induced by $\mathrm{ZnO}$ NPs from peripheral blood mononuclear cells. ${ }^{53} \mathrm{TiO}_{2}{ }^{89}$ and $\mathrm{SiO}_{2} \mathrm{NPs}^{90}$ activated inflammasomes and induced IL-1 $\beta$ release, which affected fibroblast proliferation. Ag NPs also induced inflammasome formation and triggered IL- $1 \beta$ release and subsequent caspase-1 activation. ${ }^{91}$ Size-dependent immunomodulatory effect of Au NPs has been reported that may inhibit IL-12p70 production by DCs and Th2 polarization, or promote Th17 potentiation. ${ }^{92} \mathrm{CeO}_{2}$ NPs stimulated IL-10 production from DCs and triggered a strong Th2-biased cytokine profile. On the contrary, $\mathrm{TiO}_{2} \mathrm{NPs}$ induced DCs to release IL-12 and polarize T cells to a Th1-bias. ${ }^{93} \mathrm{TiO}_{2} \mathrm{NPs}$ and nanoplatinum triggered proinflammatory cytokine production, $\mathrm{DC}$ maturation and näive $\mathrm{T}$ cell activation and proliferation. ${ }^{94,95} \mathrm{~A}$ benign $\varepsilon$-polylysine/Ag nanocomposite has been reported to modulate the relative levels of $\mathrm{CD}^{+}$ $\mathrm{T}$ cells and $\mathrm{CD} 68^{+}$macrophages and promote infected wound healing. ${ }^{96}$

\section{Synergistic antibacterial effects of nanomaterials with antibiotics or alternate antimicrobial compounds}

While most metal-based NPs are microbicidal to an array of bacteria, genetic alterations in bacteria may result in rapid evolution of resistance to $\mathrm{Ag} \mathrm{NPs},{ }^{31}$ whereas $\mathrm{Al}_{2} \mathrm{O}_{3}$ NPs trigger increased expression of conjugation-promoting genes, thus promoting horizontal transfer of antibiotic resistance genes. NPs have been tailored to subdue resistance 
by packaging multifarious antimicrobial agents, resulting in development of resistance, which is a subtle possibility since it would require multiple simultaneous gene mutations in the same bacteria. ${ }^{97,98}$

The functionalization of NPs using antibiotics (Table 3) is not only a promising nanoplatform to combat bacterial resistance but may also reduce the dose and hence toxicity of the drugs. NPs target or deliver antimicrobial agents to the infected site, thereby overcoming resistance as well as mitigating their hazardous impact on normal cells. Synergistic antibacterial efficiency of Ag NPs and antibiotics has been observed against $S$. aureus, E. coli and $P$. aeruginosa at extremely low concentrations. ${ }^{99}$ The efficacy of ampicillin coupled with Ag NPs was identical in Gram-positive and Gram-negative bacteria, unlike the difficulty in inhibition of Gram-positive bacteria with Ag NPs alone. ${ }^{39}$ Green synthesized NPs may also be used as an antibiotic adjuvant for the treatment of various bacterial infections (Table 3). Ag NPs boost the antimicrobial effects of several antibiotics, including penicillin $\mathrm{G}$, amoxicillin, vancomycin, clindamycin and erythromycin against $S$. aureus, E. coli and MDR bacteria. ${ }^{100}$ The antibiotic-functionalized NPs may promote reversal of antimicrobial resistance.

Combinatorial effect of Ag NPs with natural alternative compounds such as cinnamaldehyde ${ }^{117}$ and eugenol ${ }^{118}$ has also been reported. Se NPs conjugated with quercetin and

Table 3 Drug-nanomaterial synergy for antibacterial therapy

\begin{tabular}{|c|c|c|c|}
\hline Nanomaterials & Antibiotics & Affected bacteria & References \\
\hline \multirow[t]{11}{*}{$\mathrm{Ag} \mathrm{NPs}$} & Chloramphenicol & Salmonella typhi & 101 \\
\hline & & Enterococcus faecium, Pseudomonas aeruginosa & 102 \\
\hline & Polymyxin B, rifampicin & Acinetobacter baumannii & 103 \\
\hline & Vancomycin & Enterobacter aerogenes & 39 \\
\hline & Ampicillin & MRSA, $P$. aeruginosa, E. aerogenes, Escherichia coli & 104 \\
\hline & & E. coli, E. faecium, Streptococcus mutans, & 102 \\
\hline & & Staphylococcus aureus, $P$. aeruginosa & \\
\hline & Ciprofloxacin & VRE & 105 \\
\hline & Vancomycin & VRE, E. coli & \\
\hline & Vancomycin & MRSA & 106 \\
\hline & Clotrimazole & MRSA, S. aureus & 107 \\
\hline $\mathrm{Ag}$ NPs plus blue light & $\begin{array}{l}\text { Amoxicillin, azithromycin, } \\
\text { clarithromycin, linezolid }\end{array}$ & MRSA & 108 \\
\hline$\gamma$-Cyclodextrin-capped Ag NPs & Chloramphenicol & $\begin{array}{l}\text { P. aeruginosa, Enterococcus faecalis, Klebsiella } \\
\text { pneumoniae, S. aureus }\end{array}$ & 109 \\
\hline \multirow[t]{5}{*}{ Au NPs } & Ampicillin & MRSA, $P$. aeruginosa, E. aerogenes, E. coli & 104 \\
\hline & Vancomycin & VRE, E. coli & 110 \\
\hline & Vancomycin & MRSA & 106 \\
\hline & Kanamycin & $\begin{array}{l}\text { Streptococcus bovis, Staphylococcus epidermidis, } \\
\text { E. aerogenes, } P \text {. aeruginosa, Yersinia pestis }\end{array}$ & III \\
\hline & Streptomycin, gentamycin, neomycin & S. aureus, Micrococcus luteus, $E$. coli, $P$. aeruginosa & 54 \\
\hline \multirow[t]{2}{*}{$\mathrm{ZnO} N \mathrm{NP}$} & Ciprofloxacin, ceftazidime & MDR A. baumannii & 112 \\
\hline & $\begin{array}{l}\text { Ciprofloxacin, erythromycin, } \\
\text { methicillin, vancomycin }\end{array}$ & E. faecalis, E. faecium & 105 \\
\hline $\begin{array}{l}\mathrm{Ag} \text { NPs from leaf extract of } \\
\text { Typha angustifolia }\end{array}$ & Gentamicin, cefotaxime, meropenem & E. coli, K. pneumoniae & 113 \\
\hline \multirow[t]{2}{*}{ Ag NPs from Acinetobacter calcoaceticus } & Vancomycin & E. aerogenes & 114 \\
\hline & $\beta$-Lactam antibiotics & MDR A. baumannii, vancomycin-resistant S. mutans & \\
\hline \multirow[t]{5}{*}{$\mathrm{Ag}$ NPs from $E$. coli } & Bacitracin & E. coli, Salmonella paratyphi B & 58 \\
\hline & Ampicillin & Corynebacterium diphtheriae & \\
\hline & Kanamycin & K. pneumoniae & \\
\hline & Gentamycin & P. aeruginosa & \\
\hline & $\begin{array}{l}\text { Bacitracin, gentamycin, } \\
\text { erythromycin, ciprofloxacin }\end{array}$ & S. aureus & \\
\hline Citrate-capped Ag NPs from & Cephalothin, cefazolin, & M. luteus, Bacillus subtilis, $P$. aeruginosa, $E$. coli & 115 \\
\hline Allium sativum & chloramphenicol & & \\
\hline Au NPs from Adiantum philippense extract & Amoxicillin & MRSA & 116 \\
\hline Au NPs from Citrullus lanatus rind & Kanamycin, rifampicin & $\begin{array}{l}\text { Bacillus cereus, E. coli, Listeria monocytogenes, } \\
\text { S. aureus, S. typhi }\end{array}$ & 78 \\
\hline
\end{tabular}

Abbreviations: NPs, nanoparticles; MRSA, methicillin-resistant Staphylococcus aureus; VRE, vancomycin-resistant Enterococcus; MDR, multidrug resistant. 
acetylcholine had synergistic effect against MRSA, causing irreversible membrane damage. ${ }^{119}$ Resveratrol nanocarriers with Au NPs and Ag NPs had potent activity against Grampositive and Gram-negative bacteria. ${ }^{120}$ The combination of biologically synthesized Ag NPs (produced by Fusarium oxysporum) and oregano (Origanum vulgare) essential oil showed bactericidal effects against non-methicillin-resistant S. aureus (non-MRSA) and $\beta$-lactamase- and carbapenemaseproducing E. coli and A. baumannii strains. ${ }^{121}$ Nigella sativa essential oil-synthesized Au NPs effectively inhibited the biofilm formation of $S$. aureus and Vibrio harveyi. ${ }^{122}$

\section{Polymeric nanocomposites and nanomaterials conjugated with antibodies and other ligands and drug-NP complex for targeted delivery}

Antimicrobial NPs can be easily trapped within polymer films to form lipid-polymer hybrid NPs or nanocomposites. Enhanced biocompatibility and stability coupled with controlled release make these superior alternatives to metallic NPs. Synergistic antibacterial effects of some polymers and metal nanomaterials have been identified. The biocidal activities of $\mathrm{Ag}$ and $\mathrm{Cu}$ NPs embedded in polymer matrices have been reported to be enhanced due to release of metal ions while dampening their toxicities. ${ }^{55,123} \mathrm{Ag}$ nanocomposites have been reported to be biocidal against MRSA. ${ }^{124} \mathrm{~A}$ benign $\varepsilon$-polylysine/Ag nanocomposite demonstrated antibacterial effects against $P$. aeruginosa and $S$. aureus that was mediated by surface adherence, irreversible disruption of the membrane with subsequent penetration and inhibition of protein activity, ultimately leading to bacterial apoptosis. ${ }^{96}$ Low-density polyethylene-containing $\mathrm{ZnO}$ nanocomposites have been found to be effective against $B$. subtilis and Enterobacter aerogenes. ${ }^{125} \mathrm{Ag} / \mathrm{Fe}_{3} \mathrm{O}_{4}$ nanocomposites demonstrated high antibacterial activity against $E$. coli ${ }^{126}$ and graphene-oxide Ag nanocomposites against MRSA. ${ }^{127}$

Targeted NP delivery to the infection site could also be achieved by surface modification with ligands or antibodies, which may further improve therapeutic efficacy and reduce the side effects of antimicrobial drugs. The effectiveness of Ag NPs is also augmented with compounds such as polyethyleneimines, chitosan and glucosamine that serve as ligands and reinforce their uptake into bacterial cells. ${ }^{128}$ Chitosan has inherent antimicrobial properties due its polycationic character. Low-molecular weight chitosan-coated Ag NPs have been reported to surpass polyvinylpyrrolidone-coated Ag NPs and Ag NPs without surface stabilizer (uncoated Ag NPs) in efficacy against MRSA with enhanced biocompatibility and reduced body absorption characteristics. ${ }^{129}$ Chitosan/ $\mathrm{TiO}_{2} /$ Ag nanocomposites exhibited effective antibacterial activity via ROS generation, lactate dehydrogenase release and inhibited bacterial adhesion. ${ }^{130}$ Chitosan/Ag nanocomposites were effective against Salmonella sp., ${ }^{131}$ whereas the activity of chitosan- $\mathrm{TiO}_{2}: \mathrm{Cu}$ nanocomposite against $E$. coli and $S$. aureus was enhanced in the presence of light. ${ }^{132}$ Chitosan/ calcium silicate nanocomposites doped with $\mathrm{Ag}^{+}$exhibited antibacterial activity against $S$. aureus and $P$. aeruginosa. ${ }^{133}$ Ag NPs capped with lipoic acid were effective against Staphylococcus epidermidis and Streptococcus mutans biofilm. ${ }^{134}$ Ag-decorated poly (DL-lactide-co-glycolide) NPs exhibited high efficacy against $S$. epidermidis biofilms. ${ }^{135}$ Biodegradable lignin-core NPs coated with cationic polyelectrolytes and infused with $\mathrm{Ag}^{+}$exhibited broad-spectrum biocidal activity against Gram-positive as well as Gramnegative bacteria at lower concentrations of $\mathrm{Ag}^{+}$than the conventional Ag NPs and hence suggested as greener alternatives to Ag NPs. ${ }^{136}$ Antibacterial ( $P$. aeruginosa) activity of iron oxide NPs was also enhanced upon chitosan coating. ${ }^{137}$ Superior antibacterial activity of UV-irradiated glucosamine-functionalized Au NPs on graphene oxide against E. coli and Enterococcus faecalis has been reported that was better than kanamycin. ${ }^{138}$ Gallic acid-capped Au NPs have been found to be effective against both Gram-positive and Gram-negative bacteria. ${ }^{139}$ Synthetic peptides (containing arginine, tryptophan and cysteine termini)-immobilized Au NPs exhibited targeting capacity and activity against Staphylococci, Enterococci and antibiotic-resistant bacterial strains. ${ }^{140}$ Microbial (Ochrobactrum rhizosphaerae) glycolipoprotein-capped Ag NPs exhibited antibacterial activity against $V$. cholerae comparable to ciprofloxacin. ${ }^{141}$ Besides the targeting ligands, NPs conjugated with antibodies against surface antigen of the target microbe such as anti-protein A antibodies have been shown to have high selectivity for killing $S$. aureus. Conjugating Bi NPs to antibodies against the target has been found to be effective against MDR $P$. aeruginosa when irradiated with low-dose X-rays. ${ }^{54}$ Similarly, the $\mathrm{IgG}$ in $\mathrm{IgG}_{-} \mathrm{Fe}_{3} \mathrm{O}_{4} @ \mathrm{TiO}_{2}$ magnetic NPs has been shown to target $S$. pyogenes. ${ }^{54}$

Drug-NP complex represents another type of polymeric NPs that are highly attractive as drug delivery vehicles due to their stability, ease of functionalization and sustained release. These may be made multifunctional by incorporating different polymers. Chitosan-functionalized Au NPs adsorbed on vancomycin-encapsulated liposomes released the antibiotic 
in the presence of anti-toxin antibody secreted by $S$. aureus, inhibiting its growth. ${ }^{142}$ Lipids like phosphatidylinositol and stearylamine presented specific affinity with biofilms, thereby increasing the biofilm adhesion of liposomes. Anti-biofilm activities of phosphatidylcholine-decorated Au NPs loaded with gentamycin have been reported against $P$. aeruginosa, $S$. aureus as well as intracellular Listeria monocytogenes and E. coli. ${ }^{143}$ NP-based drug delivery could subjugate systemic toxic effects of antibiotics, decrease uptake and increase efflux of drugs, biofilm formation and intracellular bacterial infection.

\section{Conclusion and perspectives}

Bacteria are increasingly dodging extermination as they have evolved innate immune resistance strategies. Antibiotics remain the mainstay to fight bacterial infections, but episodes of resistant infections are alarmingly on the rise. The indiscriminate use of antimicrobial agents in the community, hospital and agriculture is undeniably responsible for fuelling this crisis. This also causes selective pressure, allowing only the fittest genotype to thrive, resulting in emergence of MDR bacterial strains, and emphasizing the need for surrogate therapeutic options. The emergence of resistant and more virulent strains of bacteria has outpaced the development of new antibiotics over the last few decades. NPs are now being considered as a viable alternative to antibiotics due to their biocidal and immunopotentiating properties. The polymerbased nanomaterials and metal NPs may also be exploited as antimicrobial coatings on surface of medical devices for various biomedical applications. Metallic NPs when used with the existing antibiotics for bacterial infections lower the antibiotics dosage to be administered, thereby minimizing toxicity as well as reducing the probability of development of resistance. There has been a paradigm shift towards cost-effective and ecofriendly green synthesis of antibacterial NPs. This approach holds promise alone or synergistically with antibiotics targeting various bacterial infections, paving way for future therapeutics in nanomedicine. This combinatorial approach may serve as adjunct to the existing therapies and may help to restrain the escalating nosocomial threats. However, their translation to clinics would entail an in-depth understanding of the pharmacokinetics and biodistribution of NPs.

\section{Disclosure}

The author reports no conflicts of interest in this work.

\section{References}

1. Al-Anazi KA, Al-Jasser AM. Infections caused by Acinetobacter baumannii in recipients of hematopoietic stem cell transplantation. Front Oncol. 2014;4:186.
2. Satorius AE, Szafranski J, Pyne D, et al. Complement c5a generation by staphylococcal biofilms. Shock. 2013;39(4):336-342.

3. Ubagai T, Nakano R, Nakano A, Kamoshida G, Ono Y. Gene expression analysis in human polymorphonuclear leukocytes stimulated by LPSs from nosocomial opportunistic pathogens. Innate Immun. 2015; 21(8):802-812.

4. Fallah F, Abdolghafoorian H, Sajadi Nia RS, et al. Antimicrobial resistance patterns of Acinetobacter baumannii, Pseudomonas aeruginosa and Staphylococcus aureus isolated from patients with nosocomial infections admitted to Tehran Hospitals. Arch Pediatr Infect Dis. 2015; 3(4): 32554.

5. Beyth N, Houri-Haddad Y, Domb A, Khan W, Hazan R. Alternative antimicrobial approach: nano-antimicrobial materials. Evid Based Complement Alternat Med. 2015;2015:246012.

6. Gupta A, Landis RF, Rotello VM. Nanoparticle-based antimicrobials: surface functionality is critical. F1000Res. 2016;5:F1000 Faculty Rev-364.

7. Pelgrift RY, Friedman AJ. Nanotechnology as a therapeutic tool to combat microbial resistance. Adv Drug Deliv Rev. 2013;65(13-14): $1803-1815$

8. Rai M, Kon K, Gade A, et al. Antibiotic resistance: can nanoparticles tackle the problem? In: Kon K, Rai M, editors. Antibiotic Resistance: Mechanisms and New Antimicrobial Approaches. Academic Press, Elsevier Inc. USA; 2016:121.

9. Dijkshoorn L, Nemec A, Seifert H. An increasing threat in hospitals: multidrug-resistant Acinetobacter baumannii. Nat Rev Microbiol. 2007;5(12):939-951.

10. Japoni-Nejad A, Sofian M, van Belkum A, Ghaznavi-Rad E. Nosocomial outbreak of extensively and pan drug-resistant Acinetobacter baumannii in tertiary hospital in central part of Iran. Jundishapur $J$ Microbiol. 2013;6(8):e9892.

11. Omer MI, Gumaa SA, Hassan AA, et al. Prevalence and resistance profile of Acinetobacter baumannii clinical isolates from a private hospital in Khartoum, Sudan. Am J Microbiol Res. 2015;3(2):76-79.

12. Aljindan R, Bukharie H, Alomar A, Abdalhamid B. Prevalence of digestive tract colonization of carbapenem-resistant Acinetobacter baumannii in hospitals in Saudi Arabia. J Med Microbiol. 2015;64(Pt 4): 400-406.

13. Cornejo-Juárez P, Vilar-Compte D, Pérez-Jiménez C, ÑamendysSilva SA, Sandoval-Hernández S, Volkow-Fernández P. The impact of hospital-acquired infections with multidrug-resistant bacteria in an oncology intensive care unit. Int J Infect Dis. 2015;31:31-34.

14. Ventola CL. The antibiotic resistance crisis: part 1: causes and threats. PT. 2015;40(4):277-283.

15. Lebeaux D, Ghigo JM, Beloin C. Biofilm-related infections: bridging the gap between clinical management and fundamental aspects of recalcitrance toward antibiotics. Microbiol Mol Biol Rev. 2014;78(3): 510-543.

16. Andersson DI, Hughes D, Kubicek-Sutherland JZ. Mechanisms and consequences of bacterial resistance to antimicrobial peptides. Drug Resist Updat. 2016;26:43-57.

17. Sansonetti PJ, Di Santo JP. Debugging how bacteria manipulate the immune response. Immunity. 2007;26(2):149-161.

18. Giedraitienè A, Vitkauskienè A, Naginienė R, Pavilonis A. Antibiotic resistance mechanisms of clinically important bacteria. Medicina (Kaunas). 2011;47(3):137-146.

19. Mayers D, editor. Antimicrobial Drug Resistance: Volume 1. Mechanisms of Drug Resistance. Infectious Disease. Humana Press, UK; 2009.

20. Alcalde-Rico M, Hernando-Amado S, Blanco P, Martínez JL. Multidrug efflux pumps at the crossroad between antibiotic resistance and bacterial virulence. Front Microbiol. 2016;7:1483.

21. Shaikh S, Fatima J, Shakil S, Rizvi SM, Kamal MA. Antibiotic resistance and extended spectrum beta-lactamases: types, epidemiology and treatment. Saudi J Biol Sci. 2015;22(1):90-101.

22. Blair JM, Webber MA, Baylay AJ, Ogbolu DO, Piddock LJ. Molecular mechanisms of antibiotic resistance. Nat Rev Microbiol. 2015;13(1): $42-51$. 
23. Cox G, Stogios PJ, Savchenko A, Wright GD. Structural and molecular basis for resistance to aminoglycoside antibiotics by the adenylyltransferase ANT(2")-la. MBio. 2015;6(1).

24. Yun MK, Wu Y, Li Z, et al. Catalysis and sulfa drug resistance in dihydropteroate synthase: crystal structures reveal the catalytic mechanism of DHPS and the structural basis of sulfa drug action and resistance. Science. 2012;335(6072):1110-1114.

25. Zhu X, Radovic-Moreno AF, Wu J, Langer R, Shi J. Nanomedicine in the management of microbial infection - overview and perspectives. Nano Today. 2014;9(4):478-498.

26. Dizaj SM, Lotfipour F, Barzegar-Jalali M, Zarrintan MH, Adibkia K. Antimicrobial activity of the metals and metal oxide nanoparticles. Mater Sci Eng C Mater Biol Appl. 2014;44:278-284.

27. Hernandez-Delgadillo R, Velasco-Arias D, Diaz D, et al. Zerovalent bismuth nanoparticles inhibit Streptococcus mutans growth and formation of biofilm. Int J Nanomedicine. 2012;7:2109-2113.

28. Dakal TC, Kumar A, Majumdar RS, Yadav V. Mechanistic basis of antimicrobial actions of silver nanoparticles. Front Microbiol. 2016; 7:1831.

29. Durán N, Durán M, de Jesus MB, Seabra AB, Fávaro WJ, Nakazato G. Silver nanoparticles: a new view on mechanistic aspects on antimicrobial activity. Nanomedicine. 2016;12(3):789-799.

30. Rai MK, Deshmukh SD, Ingle AP, Gade AK. Silver nanoparticles: the powerful nanoweapon against multidrug-resistant bacteria. $J$ Appl Microbiol. 2012;112(5):841-852.

31. Graves JL Jr, Tajkarimi M, Cunningham Q, et al. Rapid evolution of silver nanoparticle resistance in Escherichia coli. Front Genet. 2015;6:42.

32. Ansari MA, Khan HM, Khan AA, Cameotra SS, Saquib Q, Musarrat J. Interaction of $\mathrm{Al}_{(2)} \mathrm{O}_{(3)}$ nanoparticles with Escherichia coli and their cell envelope biomolecules. J Appl Microbiol. 2014;116(4):772-783.

33. Oktar FN, Yetmez M, Ficai D, Ficai A, Dumitru F, Pica A. Molecular mechanism and targets of the antimicrobial activity of metal nanoparticles. Curr Top Med Chem. 2015;15(16):1583-1588.

34. Łysakowska ME, Ciebiada-Adamiec A, Klimek L, Sienkiewicz M. The activity of silver nanoparticles (Axonnite) on clinical and environmental strains of Acinetobacter spp. Burns. 2015;41(2):364-371.

35. Sirelkhatim A, Mahmud S, Seeni A, et al. Review on zinc oxide nanoparticles: antibacterial activity and toxicity mechanism. Nano-Micro Lett. 2015;7(3):219-242.

36. Wong MS, Chen CW, Hsieh CC, Hung SC, Sun DS, Chang HH. Antibacterial property of Ag nanoparticle-impregnated N-doped titania films under visible light. Sci Rep. 2015;5:11978.

37. Chatterjee AK, Chakraborty R, Basu T. Mechanism of antibacterial activity of copper nanoparticles. Nanotechnology. 2014;25(13):135101.

38. Lellouche J, Friedman A, Lahmi R, Gedanken A, Banin E. Antibiofilm surface functionalization of catheters by magnesium fluoride nanoparticles. Int J Nanomedicine. 2012;7:1175-1188.

39. Franci G, Falanga A, Galdiero $S$, et al. Silver nanoparticles as potential antibacterial agents. Molecules. 2015;20(5):8856-8874.

40. Yoon KY, Hoon Byeon J, Park JH, Hwang J. Susceptibility constants of Escherichia coli and Bacillus subtilis to silver and copper nanoparticles. Sci Total Environ. 2007;373(2-3):572-575.

41. Shamaila S, Zafar N, Riaz S, Sharif R, Nazir J, Naseem S. Gold nanoparticles: an efficient antimicrobial agent against enteric bacterial human pathogen. Nanomaterials (Basel). 2016;6(4).

42. Luo Y, Hossain M, Wang C, et al. Targeted nanoparticles for enhanced $\mathrm{X}$-ray radiation killing of multidrug-resistant bacteria. Nanoscale. 2013;5(2):687-694.

43. Huo S, Jiang Y, Gupta A, et al. Fully zwitterionic nanoparticle antimicrobial agents through tuning of core size and ligand structure. ACS Nano. 2016;10(9):8732-8737.

44. Khashan KS, Sulaiman GM, Abdul Ameer FA, Napolitano G. Synthesis, characterization and antibacterial activity of colloidal $\mathrm{NiO}$ nanoparticles. PakJ Pharm Sci. 2016;29(2):541-546.

45. Ali Z, Raj B, Vishwas M, Athhar MA. Synthesis, characterization and antimicrobial activity of $\mathrm{Ce}$ doped $\mathrm{TiO}_{2}$ nanoparticles. Int J Curr Microbiol Appl Sci. 2016;5(4):705-712.
46. Neethirajan S, Clond MA, Vogt A. Medical biofilms-nanotechnology approaches. J Biomed Nanotechnol. 2014;10(10):2806-2827.

47. Lee JH, Kim YG, Cho MH, Lee J. ZnO nanoparticles inhibit Pseudomonas aeruginosa biofilm formation and virulence factor production. Microbiol Res. 2014;169(12):888-896.

48. Lellouche J, Friedman A, Gedanken A, Banin E. Antibacterial and antibiofilm properties of yttrium fluoride nanoparticles. Int J Nanomedicine. 2012;7:5611-5624.

49. Guisbiers G, Wang Q, Khachatryan E, et al. Inhibition of E. coli and S. aureus with selenium nanoparticles synthesized by pulsed laser ablation in deionized water. Int J Nanomedicine. 2016;11:3731-3736.

50. Dhanabalan K, Gurunathan K. Microemulsion mediated synthesis and characterization of CdS nanoparticles and its anti-biofilm efficacy against Escherichia coli ATCC 25922. J Nanosci Nanotechnol. 2015; 15(6):4200-4204.

51. Liakos I, Grumezescu AM, Holban AM. Magnetite nanostructures as novel strategies for anti-infectious therapy. Molecules. 2014;19(8): $12710-12726$

52. Nour El Din S, El-Tayeb TA, Abou-Aisha K, El-Azizi M. In vitro and in vivo antimicrobial activity of combined therapy of silver nanoparticles and visible blue light against Pseudomonas aeruginosa. Int $J$ Nanomedicine. 2016;11:1749-1758.

53. Esparza-González SC, Sánchez-Valdés S, Ramírez-Barrón SN, et al. Effects of different surface modifying agents on the cytotoxic and antimicrobial properties of $\mathrm{ZnO}$ nanoparticles. Toxicol In Vitro. 2016;37: 134-141.

54. Grumezescu A, editor. Nanobiomaterials in Antimicrobial Therapy: Applications of Nanobiomaterials. 1st ed. Elsevier, USA; 2016.

55. Perdikaki A, Galeou A, Pilatos G, et al. Ag and Cu monometallic and $\mathrm{Ag} / \mathrm{Cu}$ bimetallic nanoparticle-graphene composites with enhanced antibacterial performance. ACS Appl Mater Interfaces. Epub 2016 Oct 11.

56. Ashfaq M, Verma N, Khan S. Copper/zinc bimetal nanoparticlesdispersed carbon nanofibers: a novel potential antibiotic material. Mater Sci Eng C Mater Biol Appl. 2016;59:938-947.

57. Park Y. New paradigm shift for the green synthesis of antibacterial silver nanoparticles utilizing plant extracts. Toxicol Res. 2014;30(3): 169-178.

58. Gandhi H, Khan S. Biological synthesis of silver nanoparticles and its antibacterial activity. J Nanomed Nanotechnol. 2016;7:366.

59. Ghaedi M, Yousefinejad M, Safarpoor M, Khafri HZ, Purkait MK. Rosmarinus officinalis leaf extract mediated green synthesis of silver nanoparticles and investigation of its antimicrobial properties. $J$ Ind Eng Chem. 2015;25:167-172.

60. Nayak D, Ashe S, Rauta PR, Kumari M, Nayak B. Bark extract mediated green synthesis of silver nanoparticles: evaluation of antimicrobial activity and antiproliferative response against osteosarcoma. Mater Sci Eng C Mater Biol Appl. 2016;58:44-52.

61. Ahmed MJ, Murtaza G, Mehmood A, Bhatti TM. Green synthesis of silver nanoparticles using leaves extract of Skimmia laureola: characterization and antibacterial activity. Mater Lett. 2015;153:10-13.

62. Suresh G, Gunasekar PH, Kokila D, et al. Green synthesis of silver nanoparticles using Delphinium denudatum root extract exhibits antibacterial and mosquito larvicidal activities. Spectrochim Acta A Mol Biomol Spectrosc. 2014;127:61-66.

63. Du J, Singh H, Yi TH. Antibacterial, anti-biofilm and anticancer potentials of green synthesized silver nanoparticles using benzoin gum (Styrax benzoin) extract. Bioprocess Biosyst Eng. 2016;39(12):1923-1931.

64. Meng Y, Sun Y. Development of biogenic silver nanoparticle using Rosa chinensis flower extract and its antibacterial property. J Nanosci Nanotechnol. 2016;16(4):3969-3972.

65. Jun SH, Cha SH, Kim JH, Yoon M, Cho S, Park Y. Silver nanoparticles synthesized using Caesalpinia sappan extract as potential novel nanoantibiotics against methicillin-resistant Staphylococcus aureus. J Nanosci Nanotechnol. 2015;15(8):5543-5552.

66. Dhand V, Soumya L, Bharadwaj S, Chakra S, Bhatt D, Sreedhar B. Green synthesis of silver nanoparticles using Coffea arabica seed extract and its antibacterial activity. Mater Sci Eng C Mater Biol Appl. 2016;58: $36-43$. 
67. Ramesh M, Anbuvannan M, Viruthagiri G. Green synthesis of $\mathrm{ZnO}$ nanoparticles using Solanum nigrum leaf extract and their antibacterial activity. Spectrochim Acta A Mol Biomol Spectrosc. 2015;136(Pt B): 864-870.

68. Maqbool Q, Nazar M, Naz S, et al. Antimicrobial potential of green synthesized $\mathrm{CeO}_{2}$ nanoparticles from Olea europaea leaf extract. Int $J$ Nanomedicine. 2016;11:5015-5025.

69. Venkateswarlu S, Kumar BN, Prathima B, Anitha K, Jyothi NVV. A novel green synthesis of $\mathrm{Fe}_{3} \mathrm{O}_{4}$-Ag core shell recyclable nanoparticles using Vitis vinifera stem extract and its enhanced antibacterial performance. Physica B Condens Matter. 2015;457:30-35.

70. Tippayawat P, Phromviyo N, Boueroy P, Chompoosor A. Green synthesis of silver nanoparticles in aloe vera plant extract prepared by a hydrothermal method and their synergistic antibacterial activity. PeerJ. 2016;4:e2589.

71. Singh K, Panghal M, Kadyan S, Chaudhary U, Yadav JP. Green silver nanoparticles of Phyllanthus amarus: as an antibacterial agent against multi drug resistant clinical isolates of Pseudomonas aeruginosa. J Nanobiotechnology. 2014;12:40.

72. Mapara N, Sharma M, Shriram V, Bharadwaj R, Mohite KC, Kumar V. Antimicrobial potentials of Helicteres isora silver nanoparticles against extensively drug-resistant (XDR) clinical isolates of Pseudomonas aeruginosa. Appl Microbiol Biotechnol. 2015;99(24): 10655-10667.

73. Jang H, Lim SH, Choi JS, Park Y. Antibacterial properties of cetyltrimethylammonium bromide-stabilized green silver nanoparticles against methicillin-resistant Staphylococcus aureus. Arch Pharm Res. 2015;38(10):1906-1912.

74. Krishnaraj C, Jagan EG, Rajasekar S, Selvakumar P, Kalaichelvan PT, Mohan N. Synthesis of silver nanoparticles using Acalypha indica leaf extracts and its antibacterial activity against water borne pathogens. Colloids Surf B Biointerfaces. 2010;76(1):50-56.

75. Ramalingam B, Parandhaman T, Das SK. Antibacterial effects of biosynthesized silver nanoparticles on surface ultrastructure and nanomechanical properties of Gram-Negative Bacteria viz. Escherichia coli and Pseudomonas aeruginosa. ACS Appl Mater Interfaces. 2016; 8(7):4963-4976

76. Mariselvam R, Ranjitsingh AJ, Usha Raja Nanthini A, Kalirajan K, Padmalatha C, Mosae Selvakumar P. Green synthesis of silver nanoparticles from the extract of the inflorescence of Cocos nucifera (Family: Arecaceae) for enhanced antibacterial activity. Spectrochim Acta A Mol Biomol Spectrosc. 2014;129:537-541.

77. Salem W, Leitner DR, Zingl FG, et al. Antibacterial activity of silver and zinc nanoparticles against Vibrio cholerae and enterotoxic Escherichia coli. Int J Med Microbiol. 2015;305(1):85-95.

78. Patra JK, Baek KH. Novel green synthesis of gold nanoparticles using Citrullus lanatus rind and investigation of proteasome inhibitory activity, antibacterial, and antioxidant potential. Int J Nanomedicine 2015;10:7253-7264

79. Salunke GR, Ghosh S, Santosh Kumar RJ, et al. Rapid efficient synthesis and characterization of silver, gold, and bimetallic nanoparticles from the medicinal plant Plumbago zeylanica and their application in biofilm control. Int J Nanomedicine. 2014;9:2635-2653.

80. Gopinath K, Kumaraguru S, Bhakyaraj K, et al. Green synthesis of silver, gold and silver/gold bimetallic nanoparticles using the Gloriosa superba leaf extract and their antibacterial and antibiofilm activities. Microb Pathog. 2016;101:1-11.

81. Pandian CJ, Palanivel R, Dhanasekaran S. Screening antimicrobial activity of nickel nanoparticles synthesized using Ocimum sanctum leaf extract. $J$ Nanoparticles. 2016;2016:4694367.

82. Ansari MA, Khan HM, Alzohairy MA, et al. Green synthesis of $\mathrm{Al}_{2} \mathrm{O}_{3}$ nanoparticles and their bactericidal potential against clinical isolates of multi-drug resistant Pseudomonas aeruginosa. World J Microbiol Biotechnol. 2015;31(1):153-164.

83. Anand K, Tiloke C, Phulukdaree A, et al. Biosynthesis of palladium nanoparticles by using Moringa oleifera flower extract and their catalytic and biological properties. J Photochem Photobiol B. 2016;165: 87-95.
84. Khiralla GM, El-Deeb BA. Antimicrobial and antibiofilm effects of selenium nanoparticles on some foodborne pathogens. LWT - Food Sci Technol. 2015;63(2):1001-1007.

85. Sonkusre P, Singh Cameotra S. Biogenic selenium nanoparticles inhibit Staphylococcus aureus adherence on different surfaces. Colloids Surf B Biointerfaces. 2015;136:1051-1057.

86. Luo YH, Chang LW, Lin P. Metal-based nanoparticles and the immune system: activation, inflammation, and potential applications. Biomed Res Int. 2015;2015:143720.

87. Jiao Q, Li L, Mu Q, Zhang Q. Immunomodulation of nanoparticles in nanomedicine applications. Biomed Res Int. 2014;2014: 426028.

88. Hanley C, Thurber A, Hanna C, Punnoose A, Zhang J, Wingett DG. The influences of cell type and $\mathrm{ZnO}$ nanoparticle size on immune cell cytotoxicity and cytokine induction. Nanoscale Res Lett. 2009;4(12): 1409-1420

89. Yazdi AS, Guarda G, Riteau N, et al. Nanoparticles activate the NLR pyrin domain containing 3 (Nlrp3) inflammasome and cause pulmonary inflammation through release of IL-1 $\alpha$ and IL-1 $\beta$. Proc Natl Acad Sci U S A. 2010;107(45):19449-19454.

90. Peeters PM, Perkins TN, Wouters EF, Mossman BT, Reynaert NL. Silica induces NLRP3 inflammasome activation in human lung epithelial cells. Part Fibre Toxicol. 2013;10:3.

91. Yang EJ, Kim S, Kim JS, Choi IH. Inflammasome formation and IL-1 $\beta$ release by human blood monocytes in response to silver nanoparticles. Biomaterials. 2012;33(28):6858-6867.

92. Tomić S, Đokić J, Vasilijić S, et al. Size-dependent effects of gold nanoparticles uptake on maturation and antitumor functions of human dendritic cells in vitro. PLoS One. 2014;9(5):e96584.

93. Schanen BC, Das S, Reilly CM, et al. Immunomodulation and Thelper $\mathrm{TH}_{1} / \mathrm{TH}_{2}$ response polarization by $\mathrm{CeO}_{2}$ and $\mathrm{TiO}_{2}$ nanoparticles. PLoS One. 2013;8(5):e62816.

94. Schanen BC, Karakoti AS, Seal S, Drake DR 3rd, Warren WL, Self WT. Exposure to titanium dioxide nanomaterials provokes inflammation of an in vitro human immune construct. ACS Nano. 2009;3(9): 2523-2532.

95. Ghoneum M, Ghoneum A, Gimzewski J. Nanodiamond and nanoplatinum liquid, DPV576, activates human monocyte-derived dendritic cells in vitro. Anticancer Res. 2010;30(10):4075-4079.

96. Dai X, Guo Q, Zhao Y, et al. Functional silver nanoparticle as a benign antimicrobial agent that eradicates antibiotic-resistant bacteria and promotes wound healing. ACS Appl Mater Interfaces. 2016;8(39): 25798-25807.

97. Bollenbach T. Antimicrobial interactions: mechanisms and implications for drug discovery and resistance evolution. Curr Opin Microbiol. 2015;27:1-9.

98. Fischbach MA. Combination therapies for combating antimicrobial resistance. Curr Opin Microbiol. 2011;14(5):519-523.

99. Panáček A, Smékalová M, Kilianová M, et al. Strong and nonspecific synergistic antibacterial efficiency of antibiotics combined with silver nanoparticles at very low concentrations showing no cytotoxic effect. Molecules. 2015;21(1):E26.

100. Naqvi SZ, Kiran U, Ali MI, et al. Combined efficacy of biologically synthesized silver nanoparticles and different antibiotics against multidrug-resistant bacteria. Int J Nanomedicine. 2013;8: 3187-3195.

101. Thomas R, Nair AP, Kr S, Mathew J, Ek R. Antibacterial activity and synergistic effect of biosynthesized AgNPs with antibiotics against multidrug-resistant biofilm-forming coagulase-negative Staphylococci isolated from clinical samples. Appl Biochem Biotechnol. 2014;173(2): 449-460.

102. Hwang IS, Hwang JH, Choi H, Kim KJ, Lee DG. Synergistic effects between silver nanoparticles and antibiotics and the mechanisms involved. J Med Microbiol. 2012;61(Pt 12):1719-1726.

103. Wan G, Ruan L, Yin Y, Yang T, Ge M, Cheng X. Effects of silver nanoparticles in combination with antibiotics on the resistant bacteria Acinetobacter baumannii. Int J Nanomedicine. 2016;11: 3789-3800. 
104. Brown AN, Smith K, Samuels TA, Lu J, Obare SO, Scott ME. Nanoparticles functionalized with ampicillin destroy multiple-antibioticresistant isolates of Pseudomonas aeruginosa and Enterobacter aerogenes and methicillin-resistant Staphylococcus aureus. Appl Environ Microbiol. 2012;78(8):2768-2774.

105. Iram S, Akbar Khan J, Aman N, Nadhman A, Zulfiqar Z, Arfat Yameen M. Enhancing the anti-enterococci activity of different antibiotics by combining with metal oxide nanoparticles. Jundishapur $J$ Microbiol. 2016;9(3):e31302.

106. Hur YE, Park Y. Vancomycin-functionalized gold and silver nanoparticles as an antibacterial nanoplatform against methicillinresistant Staphylococcus aureus. J Nanosci Nanotechnol. 2016;16(6): 6393-6399.

107. Kalhapure RS, Sonawane SJ, Sikwal DR, et al. Solid lipid nanoparticles of clotrimazole silver complex: an efficient nano antibacterial against Staphylococcus aureus and MRSA. Colloids Surf B Biointerfaces. 2015;136:651-658.

108. Akram FE, El-Tayeb T, Abou-Aisha K, El-Azizi M. A combination of silver nanoparticles and visible blue light enhances the antibacterial efficacy of ineffective antibiotics against methicillin-resistant Staphylococcus aureus (MRSA). Ann Clin Microbiol Antimicrob. 2016;15(1):48.

109. Gannimani R, Ramesh M, Mtambo S, Pillay K, Soliman ME, Govender P. $\gamma$-Cyclodextrin capped silver nanoparticles for molecular recognition and enhancement of antibacterial activity of chloramphenicol. J Inorg Biochem. 2016;157:15-24.

110. Gu H, Ho PL, Tong E, Wang L, Xu B. Presenting vancomycin on nanoparticles to enhance antimicrobial activities. Nano Lett. 2003;3(9): 1261-1263.

111. Payne JN, Waghwani HK, Connor MG, et al. Novel synthesis of kanamycin conjugated gold nanoparticles with potent antibacterial activity. Front Microbiol. 2016;7:607.

112. Ghasemi F, Jalal R. Antimicrobial action of zinc oxide nanoparticles in combination with ciprofloxacin and ceftazidime against multidrugresistant Acinetobacter baumannii. J Glob Antimicrob Resist. 2016; 6:118-122.

113. Gurunathan S. Biologically synthesized silver nanoparticles enhances antibiotic activity against gram-negative bacteria. $J$ Ind Eng Chem. 2015;29:217-226.

114. Singh R, Wagh P, Wadhwani S, et al. Synthesis, optimization, and characterization of silver nanoparticles from Acinetobacter calcoaceticus and their enhanced antibacterial activity when combined with antibiotics. Int J Nanomedicine. 2013;8:4277-4290.

115. Hari N, Thomas NK, Nair AAJ. Comparative study on the synergistic action of differentially synthesized silver nanoparticles with $\beta$-cephem antibiotics and chloramphenicol. J Nanosci. 2014;2014:201482.

116. Kalita S, Kandimalla R, Sharma KK, Kataki AC, Deka M, Kotoky J. Amoxicillin functionalized gold nanoparticles reverts MRSA resistance. Mater Sci Eng C Mater Biol Appl. 2016;61:720-727.

117. Ghosh IN, Patil SD, Sharma TK, Srivastava SK, Pathania R, Navani NK. Synergistic action of cinnamaldehyde with silver nanoparticles against spore-forming bacteria: a case for judicious use of silver nanoparticles for antibacterial applications. Int J Nanomedicine. 2013;8:4721-4731.

118. Perugini Biasi-Garbin R, Saori Otaguiri E, Morey AT, et al. Effect of eugenol against Streptococcus agalactiae and synergistic interaction with biologically produced silver nanoparticles. Evid Based Complement Alternat Med. 2015;2015:861497.

119. Huang X, Chen X, Chen Q, Yu Q, Sun D, Liu J. Investigation of functional selenium nanoparticles as potent antimicrobial agents against superbugs. Acta Biomater. 2016;30:397-407.

120. Park S, Cha SH, Cho I, et al. Antibacterial nanocarriers of resveratrol with gold and silver nanoparticles. Mater Sci Eng C Mater Biol Appl. 2016;58:1160-1169.

121. Scandorieiro S, de Camargo LC, Lancheros CA, et al. Synergistic and additive effect of oregano essential oil and biological silver nanoparticles against multidrug-resistant bacterial strains. Front Microbiol. 2016;7:760.
122. Manju S, Malaikozhundan B, Vijayakumar S, et al. Antibacterial, antibiofilm and cytotoxic effects of Nigella sativa essential oil coated gold nanoparticles. Microb Pathog. 2016;91:129-135.

123. Palza H. Antimicrobial polymers with metal nanoparticles. Int J Mol Sci. 2015;16(1):2099-2116.

124. Shurygina IA, Shurygin MG, Sukhov BG. Nanobiocomposites of metals as antimicrobial agents. In: Kon K, Rai M, editors. Antibiotic Resistance: Mechanisms and New Antimicrobial Approaches. Academic Press, Elsevier Inc., USA; 2016:167-182.

125. Esmailzadeh H, Sangpour P, Shahraz F, Hejazi J, Khaksar R. Effect of nanocomposite packaging containing $\mathrm{ZnO}$ on growth of Bacillus subtilis and Enterobacter aerogenes. Mater Sci Eng C Mater Biol Appl. 2016;58:1058-1063.

126. Ghaseminezhad SM, Shojaosadati SA. Evaluation of the antibacterial activity of $\mathrm{Ag} / \mathrm{Fe}_{3} \mathrm{O}_{4}$ nanocomposites synthesized using starch. Carbohydr Polym. 2016;144:454-463.

127. de Moraes AC, Lima BA, de Faria AF, Brocchi M, Alves OL. Graphene oxide-silver nanocomposite as a promising biocidal agent against methicillin-resistant Staphylococcus aureus. Int J Nanomedicine. 2015; 10:6847-6861.

128. Azevedo MM, Ramalho P, Silva AP, Teixeira-Santos R, Pina-Vaz C, Rodrigues AG. Polyethyleneimine and polyethyleneimine-based nanoparticles: novel bacterial and yeast biofilm inhibitors. $J$ Med Microbiol. 2014;63(Pt 9):1167-1173.

129. Peng Y, Song C, Yang C, Guo Q, Yao M. Low molecular weight chitosan-coated silver nanoparticles are effective for the treatment of MRSA-infected wounds. Int J Nanomedicine. 2017;12:295-304.

130. Natarajan S, Bhuvaneshwari M, Lakshmi DS, Mrudula P, Chandrasekaran N, Mukherjee A. Antibacterial and antifouling activities of chitosan/ $\mathrm{TiO}_{2} / \mathrm{Ag}$ NPs nanocomposite films against packaged drinking water bacterial isolates. Environ Sci Pollut Res Int. 2016;23(19):19529-19540.

131. Arjunan N, Kumari HL, Singaravelu CM, Kandasamy R, Kandasamy J. Physicochemical investigations of biogenic chitosan-silver nanocomposite as antimicrobial and anticancer agent. Int J Biol Macromol. 2016; 92:77-87.

132. Raut AV, Yadav HM, Gnanamani A, Pushpavanam S, Pawar SH. Synthesis and characterization of chitosan- $\mathrm{TiO}_{2}: \mathrm{Cu}$ nanocomposite and their enhanced antimicrobial activity with visible light. Colloids Surf B Biointerfaces. 2016;148:566-575.

133. El-Nahrawy AM, Ali AI, Abou Hammad AB, Youssef AM. Influences of Ag-NPs doping chitosan/calcium silicate nanocomposites for optical and antibacterial activity. Int J Biol Macromol. 2016; 93(Pt A):267-275.

134. Niska K, Knap N, Kędzia A, Jaskiewicz M, Kamysz W, InkielewiczStepniak I. Capping agent-dependent toxicity and antimicrobial activity of silver nanoparticles: an in vitro study. Concerns about potential application in dental practice. Int J Med Sci. 2016;13(10):772-782.

135. Takahashi C, Matsubara N, Akachi Y, et al. Visualization of silverdecorated poly (DL-lactide-co-glycolide) nanoparticles and their efficacy against Staphylococcus epidermidis. Mater Sci Eng C Mater Biol Appl. 2017;72:143-149.

136. Richter AP, Brown JS, Bharti B, et al. An environmentally benign antimicrobial nanoparticle based on a silver-infused lignin core. Nat Nanotechnol. 2015;10(9):817-823.

137. Mukherjee M, De S. Inactivation of Pseudomonas aeruginosa by chitosan coated iron oxide nanoparticles. Recent Pat Biotechnol. 2016; 10(1):133-139.

138. Govindaraju S, Samal M, Yun K. Superior antibacterial activity of GlcN-AuNP-GO by ultraviolet irradiation. Mater Sci Eng C Mater Biol Appl. 2016;69:366-372.

139. Kim DY, Kim M, Shinde S, Sung JS, Ghodake G. Cytotoxicity and antibacterial assessment of gallic acid capped gold nanoparticles. Colloids Surf B Biointerfaces. 2017;149:162-167.

140. Kuo YL, Wang SG, Wu CY, et al. Functional gold nanoparticle-based antibacterial agents for nosocomial and antibiotic-resistant bacteria. Nanomedicine (Lond). 2016;11(19):2497-2510. 
141. Gahlawat G, Shikha S, Chaddha BS, Chaudhuri SM, Mayilraj S, Choudhury AR. Microbial glycolipoprotein-capped silver nanoparticles as emerging antibacterial agents against cholera. Microb Cell Fact. 2016;15:25.

142. Pornpattananangkul D, Zhang L, Olson S, et al. Bacterial toxintriggered drug release from gold nanoparticle-stabilized liposomes for the treatment of bacterial infection. $J$ Am Chem Soc. 2011;133(11): 4132-4139.
143. Mu H, Tang J, Liu Q, Sun C, Wang T, Duan J. Potent antibacterial nanoparticles against biofilm and intracellular bacteria. Sci Rep. 2016;6:18877.

International Journal of Nanomedicine

\section{Publish your work in this journal}

The International Journal of Nanomedicine is an international, peerreviewed journal focusing on the application of nanotechnology in diagnostics, therapeutics, and drug delivery systems throughout the biomedical field. This journal is indexed on PubMed Central, MedLine, CAS, SciSearch $®$, Current Contents $\circledR /$ Clinical Medicine,
Journal Citation Reports/Science Edition, EMBase, Scopus and the Elsevier Bibliographic databases. The manuscript management system is completely online and includes a very quick and fair peer-review system, which is all easy to use. Visit http://www.dovepress.com/ testimonials.php to read real quotes from published authors.

Submit your manuscript here: http://www.dovepress.com/international-journal-of-nanomedicine-journal 